\title{
An Analysis of the Disparities, Divergences and Differences in Financial Structures of Primary Dealer (PD) Banks and Non-primary Dealer (NPD) Banks
}

\author{
Şenol Babuşcu ${ }^{1} \&$ Adalet Hazar $^{2}$ \\ ${ }^{1}$ Banking Department, Başkent Üniversitesi TBF Bankacılık Bölümü, Ankara, Turkey \\ ${ }^{2}$ Banking Specialist, Akademi Consulting \& Training, Ankara, Turkey \\ Correspondence: Şenol Babuşcu, Banking Department, Başkent Üniversitesi TBF Bankacılık Bölümü, Bağlıca \\ Köyü, Ankara, Turkey, Tel: 90-312-246-6666. E-mail: babuscu@baskent.edu.tr \& Adalet Hazar, Nenehatun \\ Caddesi 42/2 Küçükesat, Ankara, Turkey. Tel: 90-312-446-5801. E-mail: adalethazar@gmail.com
}

Received: August 24, 2012

Accepted: September 20, 2012

Online Published: October 16, 2012

doi:10.5539/ibr.v5n11p121

URL: http://dx.doi.org/10.5539/ibr.v5n11p121

\begin{abstract}
The primary purpose of this study is to analyze and discuss the impact of the primary dealership mechanism utilized in relation to the issuance of Government Domestic Borrowing Securities (GDBS) on the financial structures of the banks. Subsequent to a thorough research and an adequate literature scan on the origins and development of the primary dealer system, our analytical approach is pillared initially on expounding on the core elements of the model, while summarizing financial data of the PD banks and NPD banks under coverage. In the same context, the discriminant analyses are aimed at exploring and revealing how PD banks and NPD banks are decoupled and disengaged in regard to their financial ratios, as well as illustrating the effect of capital ownership and the scale factor on the underlined differentiation. Consequentially, it has been ascertained through the findings of the analyses that i) some ratios have engendered a meaningful segregation of the PD banks and NPD banks, and ii) they have precipitated virtually no discernible distinction among the non-resident banks in regard to their functions as a primary dealer, iii) the financial structure of small-scale PD banks were observed to have sustained fiscal duress and constraints, while the disparity and divergence among large-scale banks became more manifest, delineated into PD banks and NPD banks in more explicit terms, and iv) the prevalence of an effect on the ownership configuration of the PD banks were encountered to be less frequent.
\end{abstract}

Keywords: primary dealership, Government Domestic Borrowing Securities, banking sector

\section{Introduction}

The fundamental meaning of the primary dealership term alludes to financial institutions pre-assigned and mandated to assume roles in the execution of bid-and-offer transactions of any asset or security representing public debt instruments in an organized and regulated market, subject to benchmark rates created as a consequence of the supply- and- demand pattems. The essential objectives, goals and strategic targets of the primary dealers aligned with the primary dealer mechanism could be summarized as enhancing effectivity and efficiency of the primary market operations and facilitating the smooth functioning of the secondary markets.

Glanced with a globally-focused perspective, the primary dealership scheme refers to a public debt financing structure, featuring financial entities considered to be a party to such operations, and selected on the basis of pre-determined criteria and qualifications to participate in scheduled auctions organized for the issuance of stocks, bonds, notes, bills, debentures etc. with the aim of augmenting the effectiveness of the primary markets and therewith also to facilitate the operation of the secondary markets.

The first practical application in our country of this unique borrowing model, incepted for different assets in diverse markets, was destined towards the Government Domestic Borrowing Securities (GDBS), structured to undertake the fulfillment of the public sector's financing requirements with an optimal design for the most favorable cost and most plausible benefit. Created in 1998, the Domestic Debt Consultative Board began to closely monitor the developments and cross-current traits in the macroeconomic domain, as senior policy-related officials from the Treasury Undersecretariat and the Central Bank of Turkey, as well as representatives of the banks actively participating in the outright purchase of Government Domestic Borrowing Securities (GDBS) regularly 
joined the Board's deliberations. By inference, it is evident that the Board acted as a de facto progenitor of the concept of primary dealership system. As a matter of fact, banks such as Türkiye İş Bankası and Akbank which partook nascent roles in the works of the Domestic Debt Consultative Board during that evolutionary episode, are poised today as primary dealers (Demir, 2004).

Congruent with its universal essence and aims, the primary dealer system began to operate in our country in its entirety since 2003, with the Treasury Undersecretariat constituting one party of the transactions and a specific number of banks designated and mandated as primary dealers positioned as the counter-party. The Treasury Undersecretariat determines and publicizes the selection criteria, pre-requisites and principles for the banks to be assigned as primary dealers, as banks fulfilling such qualifications and enthusiastic to act as primary dealers prevail in their activities and market operations solely within the framework of the rights and privileges appertaining unto their assignments as per to a contract.

In this manner, specific banks are assigned and mandated as primary dealers to enhance and amplify the liquidity of both the primary and secondary markets, and only these banking institutions are allowed to participate in the Treasury auctions. Through this system, emphasis is placed on broadening and further advancing the primary dealership mechanism - strategic objectives concocted to enlarge the liquidity of the GDBS on the secondary market, and therewith deepening the liquidity aspect of the over-all secondary market operations.

Doubtless to mention, the development and sophistication of the secondary market would invariably facilitate the borrowing and debt finance tasks of the Treasury, granting it an operational flexibility. As a by-product of this system, the issuance and transaction volumes pertaining to the GDBS are expanded through intensified purchase-and-sale deals. In the financial structures of the local and non-resident PD banks, classified and permitted to operate in the primary dealership system as described above, it has been observed that the financial constructs of the NPD banks displayed a composition that differed substantially from the other banks.

Hence, the objective of this study is to compare the financial values and components of the primary dealer banks and the non-primary dealer banks, and put forth, with circumstantial statistical evidence and justification, findings on how operations as a primary dealer might eventually influence the financial structure of the banks concerned.

\section{Literature Review}

Principal functions of the primary dealership mechanism were studied and ascertained extensively on the basis of the data-set compiled by Samita Sareen (2011), and composed of securities belonging to the Canadian government. Fundamentally, the paper argues that such a system ensures the sustainability of the regular, smooth and prudent operation of markets where debt securities issued by the state are traded. In contrast, however, there is an unambiguous mention of the effect that the primary dealership system defaults during times of crises, instigating and unleashing detrimental consequences particularly for the primary dealer banks. In several countries, it is vividly asserted, the primary dealership system effectuates the termination of the primary dealer bank's activities (as observed direly in the case of Lehman Brothers).

Another research performed by Vladimir Sokolov (2011) focuses specifically on the factors that influence the bond rates. In this respect, Sokolov's work employed the Fed data embodying the 2001-2008 period and attempts to depict the primary dealers active in that term as forecasters possessing key determinant functions in the term repo yields by measuring the net investments of the primary dealers in the repo market during the covered time-frame. The study adopted the expectation hypothesis, while the accuracy of the hypothesis put forward was tested by different variables such as the Cochrane-Piazzesi factor.

Another research paper released by Marco Arnone and Piero Ugolini (2005) exhibits the findings and results of this application in countries where the primary dealership was implemented, as of 2001. The underlying motivation for the study was to establish whether primary dealership makes a noticeable contribution to the development of the financial system in a chosen country. The study reached the conclusion that this system contributed significantly to the effectivity and sophistication of the primary and secondary markets in connection with the public debt instruments. To a great extent, recommendations for adoption of the system are frequent for the countries covered under the research.

Aydin (2005) scrutinized the purposes and benefits of the primary dealership system. His research incorporates observations on several countries, including Turkey, as case studies for gauging the implementation aspect of the primary dealer system. A comparison is made by creating a performance index, derived from data linked to the banks and the sector, and used as a benchmark, concluding that the primary dealership system makes considerable contributions both to the financial markets and the economy, as a whole. Nevertheless, the assessments section boldly underlines the fact that the GDBS markets are still shallow and exude the image of remoteness from 
adequate liquidity, and as such are fraught with a plethora of risks in respect of the primary dealers and concludes by putting forth some recommendations to resolve the predicament.

Yllmaz (2005), on the other hand, focuses poignantly on the transformations transpiring in the balance-sheets and income statements of the primary dealer banks, analyzing profoundly the stock of GDBS retained by the primary dealer banks and the progress in the pattern of interest income earned on the securities, entered under the over-all "interest income" column. The study underscores the gross benefit the system provides to the Treasury Undersecretariat, and emphasizes the importance and necessity for the banks, brokerage houses, investment trusts and unit funds, insurance and pension-retirement funds and investment banks to participate in this market and elevate their market shares.

Wolfgang Breuer (1999) touches predominantly on the intervention methods of the government in the primary and secondary markets with the purpose of maximizing its revenues in bond issues. In the same context, there is a clear reference to primary dealership architecture as a vehicle to optimize the success of debt auctions. Primary dealership is identified as one of the means of intrusion. The paper concludes that a primary dealership system created with the participation of a limited number of authorized dealers would provide benefit and prove advantageous only in situations and market circumstances under restrained competitive environment among heterogeneous primary dealers. Moreover, the study stipulates that price interventions attempted by the state would never pose an alternative to the primary dealer system. Finally, it is purported that since the primary dealer bank is entitled to innumerous privileges, it would be irrelevant and unwarranted for the public entity to pay an undue price.

\section{Primary Dealer System and Turkey}

Under the "Stand-by" Agreement concluded with the IMF at the end of 1999 and implemented immediately thereafter, the complementary program conceived to combat inflation and the correlated economic re-structuring steps, the primary dealership system was identified as a structural benchmark and performance criterion, envisaged to foster the liquidity of the Government Domestic Borrowing Securities, reduce and minimize the borrowing cost of the state, considered within the scope of the government's public debt management pursuits. Subsequently, primary dealers were determined at the end of April of 2000, as the system was initiated by the Treasury Undersecretariat on May 8, 2000 (Aydın, 2005). At the outset, the primary dealership system hosted 19 banks (See Appendix 1a), while the operational terms of the banks selected for the May 1, 2000-April 30, 2001 period were deemed to be valid and effective for one year (Aydın, 2005).

During the initial implementation phase of the system, the banks applying to qualify for designation to possess the primary dealer status were required to fulfill criteria, considered for evaluation congruent with eligibility; Capital adequacy ratio must be minimum 8\% (Note 1). "Foreign Currency Net General Position / Capital Base" standard ratio must be (+,-) maximum $20 \%$ (Note 2,3 ). Aggregate total of the equity resources must be minimum TL10 trillion, excluding the retained profit and revaluation differentials. "Non-Performing Receivables (Net) / Stockholders' Equity (excluding retained profit)" ratio must be maximum 25\%. "Non-Performing Receivables (Gross) / Loans" ratio must be maximum 10\%. Quarterly total turnover volume of the purchase-and-sale transactions of GDBS in the secondary market must be in excess of TL100 trillion (Note 4, 5). Quarterly total turnover volume of the purchases of the GDBS in the primary market must be in excess of TL40 trillion (Note 6).

In addition to the synchronized functions in the primary and secondary markets, along with sizeable turnovers accomplished in the repurchase agreement-reverse repo transactions, outright purchase-and-sale deals, and participation in the ISE's Bonds and Bills Market, as well as maintaining a sound and adequate administrative structure were other supportive and complementary factors that were taken into consideration during the evaluation process of the applicant banks for designation as primary dealers (Aydın, 2005).

As publicized in the Central Bank of Turkey's Press Release, dated September 3, 2002 and numbered 2002-73, “... the primary dealership system was initiated by the Undersecretariat of Treasury in May 2000 with the aim of achieving effectiveness in public debt management, attaining stability in public borrowing, deepening the secondary markets for Government Domestic Borrowing Securities and improving the financial system. However, this program had to be abandoned de facto due to the crisis that broke out in November 2000, and de jure with the expiration of contracts made with the primary dealer banks in May 2001. In 2001, the Treasury launched another study in order to reactivate the primary dealer system and determined its guiding principles. Finally, the primary dealer system was reintroduced on September 2, 2002."

In the same announcement, there was a special stress placed on the necessity for a deepening of the financial markets in order for the monetary and fiscal policies to be effective, adding that there was no skepticism that the primary dealership system will contribute substantially to the further deepening of the financial markets. 
Regularly disclosing the selection criteria for the financial institutions to be eligible and qualified for performing as primary dealers, the Treasury Undersecretariat circulated a Press Release on December 16, 2011, concerning the Adequacy Criteria for primary dealers in 2012as follows (Note 7): (1) In order for a candidate bank to be assigned and mandated to operate as a primary dealer, its latest financial tables and statements, to be externally audited and submitted to the Banking Regulatory and Supervision Agency, must incorporate the following; equity Capital Adequacy Standard Ratio must be minimum 12\%, total liquidity adequacy ratio pertaining to the second maturity slice must be minimum 100\% (Note 8). (2) In the last preceding 12-month period, aggregate of purchases in GDBS issues in the primary market must be minimum TL0,9 billion, and aggregate of transactions conducted in the secondary market must be minimum TL4,6 billion (Note 9).

The primary dealer system is divided into four periods, encompassing quarterly terms of January-March, April-June, July-September and October-December. Banks enthusiastic to take part in the primary dealership system are obliged to apply to the Treasury Undersecretariat in written one month, at the latest, prior to the commencement of each period. The Treasury Undersecretariat appraises the applicants on the basis of the pre-determined criteria for eligibility and specifies the primary dealers and, provided that the assignees are final, it shares the information with the general public.

In the Contract that the Treasury Undersecretariat concludes and countersigns regularly with the assigned and mandated primary dealers, the liabilities, obligations and responsibilities of the contractual parties are enumerated, as the foremost and important sections in that realm are provided here-below (Note 10):

Privileges of the Primary Dealer: the primary dealer is exempt from the collateral requirement for participation in auctions. The primary dealer has the right to submit non-competitive bids before the auctions (Note 11). The primary dealer has the right to submit option bids after an auction until 14:00 p.m. on the issue date, effective from the disclosure of the results of the auction. The Treasury Undersecretariat conducts cash operations in the money markets with primary dealer banks. The primary dealers have the exclusive right to participate in the "TAP" sales (Note 12). The primary dealer has the exclusive right to serve as an intermediary in "public offerings" of GDBS. The primary dealer has the exclusive right to participate in Buy-back and Switching auctions. The primary dealers have the right to participate in the Primary Dealership Consultative Board with two representatives (Note 13). The primary dealers may act as a Party in GDBS borrowing and lending transactions in the GDBS Lending Market, established within the realm of the Central Bank of Turkey.

Liabilities of the Primary Dealer: the liabilities of the primary dealer covering the transactions conducted on the primary market is the purchase of at least the amount obtained by dividing the sum produced through multiplication by 0.6 of the minimum net total for each quarterly period of the GDBS programmed to be issued or already issued by the Undersecretariat with the number of primary dealers operating in the market. Again to be applicable to the primary market transactions, the primary dealers are obliged to purchase at least the amount obtained by dividing the sum produced through multiplication by 0.36 of the minimum net total this time for monthly terms of the GDBS programmed to be issued or already issued by the Undersecretariat with the number of primary dealers operating in the market. The primary dealers are liable to ensure and enhance the liquidity of the GDBS in the secondary market. In this framework, and to achieve this objective, the primary dealers are compelled on every trading day to quote bid and offer prices continuously for benchmark securities transacted on the Istanbul Stock Exchange's (ISE) Bonds and Bills Market for a period of minimum three months. The primary dealers shall in no way whatsoever act in a manner and conduct that will distort the competitive environment in the primary market.

In addition to the rights, privileges and liabilities of the primary dealer, liabilities for the Treasury Undersecretariat were also specified. For example: the Treasury Undersecretariat shall consult the primary dealers and engage in the exchange of views and opinions with the primary dealers on issues of borrowing policy and new borrowing instruments.

Furthermore, the Treasury Undersecretariat shall regularly inform the Primary Dealership Consultative Board on budget performance, financing program, borrowing strategies and also in matters relating to macroeconomic topics and developments. By virtue of that practice, the primary dealers will be kept informed and advised on important and significant issues, encompassing the current market conditions as well as the forward-looking strategies that will be pursued by the policy-designers.

In case the primary dealers breach and default on abiding by and complying with the provisions and terms of the Contract, the Treasury Undersecretariat may resort to an outright cancellation, revocation and annulment of the Contract if the Treasury Undersecretariat serves notice on such default and such default is not modified or alleviated by the primary dealer in due course of time. On the other hand, the Central Bank of Turkey also sets 
different interest rates applicable to the primary dealer banks within the scope of its open market operations. The applicable interest rate that will be implemented by the primary dealer banks in their repurchase-agreement transactions may emerge below the lending interest rate proclaimed by the Central Bank of Turkey (Koçyiğit, 2009). As a matter of fact, as disclosed by the Central Bank of Turkey relating to the proceedings incorporated into the Monetary Policy Council Resolution, numbered 2012-29, and dated April 18, 2012, the lending interest rate emerged at 11.5 percent, while the borrowing facility rate allowed for the primary dealer banks in their repurchase-agreement transactions within the framework of open market transactions was fixed as $11 \%$.

\section{Effects Analysis of Primary Dealer Functions on Banks' Financial Tables}

\subsection{Model}

Multi-variate discriminant analyses attempt to forecast one (or more than one) linear correlation that illustrate how groups of more than one differ and diverge through the aid of statistically meaningful variables (Rencher, 1995). The specified relationship(s) are as follows:

$$
Z=a_{1} X_{1}+a_{2} X_{2}+a_{3} X_{3}+\ldots \ldots \ldots+a_{p} X_{p}
$$

Here, $Z$ denotes the discriminant value, $X_{i}$ the i-variable and the ai the i-variable and the concerned coefficient. The coefficients of the above linear relationship could be obtained only through the elevation of the inter-group standard distance to its maximum value (Flury \& Riedwyl, 1990). The standard distance could be defined as follows for the two groups:

$$
\mathrm{D}^{2}=\frac{\left[a^{\prime}\left(\bar{y}_{\text {group } 1}-\bar{y}_{\text {group } 2}\right)\right]^{2}}{a^{\prime} S_{P L} a}
$$

Here, $\mathrm{D}^{2}$ depicts the square of the standard distance, $\bar{y}_{k}$ the average vectors of the $\mathrm{k}$ group variables, $\mathrm{a}^{\prime}$ the coefficient vector of the above linear correlation, and $\mathrm{S}_{\mathrm{FL}}$ the weighted common covariance matrix of the groups. The coefficients vector of the linear correlation that raises the above standard distance (2) to its highest value emerges as $a$, while the standard distance could attain its highest value if and when it is calculated in the manner as provided below (Rencher, 1995):

$$
a=S_{P L}^{-1}\left(\bar{y}_{\text {group } 1}-\bar{y}_{\text {group } 2}\right)
$$

Here, $S_{P L}^{-1}$ is the inverse of the common covariance matrix.

The zero hypothesis purporting that the averages of group variables are equal to each other are tested by means of the Wilks' $\Lambda$ statistics, or through the $\chi^{2}$ (Khi-square) statistics, which, in contrast to the previous approach, could be calculated with relative ease. On the other hand, whether each of the variables generally accepted and perceived as differentiating the groups are redundant from a statistical perspective may be subjected to a test with the following partial F-statistics (Srivastava \& Carter, 1983):

$$
F=(v-p+1) \frac{T_{p}^{2}-T_{p-1}^{2}}{v+T_{p-1}^{2}}
$$

Here, $T_{p}^{2}$ Hotelling is $T^{2}$-statistics, as its degree of resilience is $\mathrm{sd}=\mathrm{v}-\mathrm{p}+1$. Also, the $T^{2}{ }_{p}$ is a statistics that includes the p-quantity variable, and the $\mathrm{T}_{\mathrm{p}-1}^{2}$ is a statistics that excludes the variable subjected to the test. Hotelling $T^{2}$ statistics is as follows:

$$
T^{2}=\frac{n_{\text {group } 1} n_{\text {group } 2}}{n_{\text {group } 1}+n_{\text {group } 2}}\left(y_{\text {group } 1}^{-}-y_{\text {group } 2}^{-}\right)^{\prime} S_{P L}^{-1}\left(y_{\text {group } 1}^{-}-y_{\text {group } 2}^{-}\right)
$$

Here, $n$ portrays the number of observations. Other variables conform to the descriptions offered above. The SPSS statistics program was employed in the solution of the discriminants, while the production of some charts such as the histogram drawings and complementary calculations were duly fulfilled by the authors.

\subsection{Pertinent Data}

Expedient with the ultimate purpose, the data-base of the research was compiled from facts and figures derived from nine annual reports issued by the Turkish Banks Association as well as data produced from the externally audited financial statements, covering fiscal years of 2003 through 2011 for a group of 11 primary dealer (PD) deposit-taking banks and the other group comprised of 10 non-primary dealer banks (Note 14). Banks belonging to both groups are identified in the Appendix $1 \mathrm{~b}$ and Appendix 1c. The financial indicators (ratios) tested statistically and generally accepted as instigating the differentiation of the groups are as follows: Capital Adequacy (CA), 
Asset Quality (AQ), Liquidity (L), Profitability (P), Revenues and Expenditures (RE), Operational Ratios (OR) and Sectoral Shares (SS). For each of these, and to serve as priority indicators, pre-selected three ratios (variables) were employed for the purposes of the analysis (Note 15). According to this, the variables deemed to possess the potential of differentiating the two groups composed of the PD banks and NPD banks comprised a total of 21 financial ratios (see Appendix 2 for the list of variables). In this manner, an aggregate of 189 x $21=3,969$ observations (records) were used in the analyses. The annual averages and standard deviation of the ratios employed in the analyses for the period of 2003-2011 are provided in Table 1, split into categories as the PD and NPD.

Table 1. Averages and Deviations of PD Banks and NPD Banks for the Period of 2003-2011

\begin{tabular}{|c|c|c|c|c|}
\hline \multirow[b]{2}{*}{ Ratios } & \multicolumn{2}{|c|}{ PD Banks } & \multicolumn{2}{|c|}{ NPD Banks } \\
\hline & Average & St. Deviation & Average & St. Deviation \\
\hline CA1 & 20,89 & 14,12 & 21,81 & 11,15 \\
\hline $\mathrm{CA} 2 * *$ & 11,93 & 3,09 & 14,54 & 5,56 \\
\hline $\mathrm{CA} 3 * *$ & 7,33 & 3,87 & 9,91 & 4,64 \\
\hline P1 & 5,32 & 6,93 & 4,92 & 4,73 \\
\hline AQ2** & 29,62 & 14,62 & 20,75 & 11,99 \\
\hline AQ3 & 49,82 & 14,70 & 49,32 & 18,35 \\
\hline L1 & 32,93 & 11,06 & 36,60 & 17,44 \\
\hline $\mathrm{L} 2 *$ & 41,36 & 14,42 & 47,15 & 21,84 \\
\hline L3 & 38,56 & 17,05 & 37,89 & 22,83 \\
\hline PRO1** & 15,48 & 21,00 & 7,95 & 11,69 \\
\hline PRO2** & 1,86 & 1,66 & 0,91 & 2,35 \\
\hline PRO3 & 53,16 & 59,04 & 39,44 & 77,00 \\
\hline RE1* & 183,01 & 43,33 & 211,48 & 109,61 \\
\hline $\mathrm{RE} 2 * *$ & 138,17 & 17,44 & 126,42 & 24,24 \\
\hline RE3 & 82,38 & 7,99 & 81,81 & 11,79 \\
\hline OR $1 * *$ & 1,52 & 0,59 & 2,43 & 1,07 \\
\hline $\mathrm{OR} 2 *$ & 49,58 & 12,67 & 56,34 & 19,93 \\
\hline OR3 & 1,12 & 1,48 & 0,93 & 1,30 \\
\hline $\mathrm{SS} 1 * *$ & 7,82 & 4,93 & 0,62 & 0,72 \\
\hline $\mathrm{SS} 2 * *$ & 7,58 & 3,96 & 0,74 & 0,91 \\
\hline $\mathrm{SS} 3 * *$ & 8,20 & 5,50 & 0,62 & 0,68 \\
\hline
\end{tabular}

Note: See Appendix 2 for the definition of the ratios (variables). According to the * and **: Wilk's $\Lambda$ and F-statistics, the ratio averages between the PD banks and NPD banks show that the differences are meaningful and rather quite meaningful.

As may be inferred also from a study of the Table above, statistically meaningful and quite meaningful differences were detected in 12 processed ratios out of 21, belonging to the data of the PD banks and the NPD banks. Such differences are most manifest in the high profitability (PRO), the lower values in their operating ratios (OR) and high sector shares of the PD. It is evident that the high ratios noticeable in the sector shares are attributable to the "sound bank" criteria employed by the Treasury Undersecretariat in selecting the PD banks. Within this framework, the fact that essentially public banks possessing large-scale sector shares were chosen as PD banks is self-explanatory for the discrepancy. However, an interesting aspect at this point is whether the market shares of the PD banks (total assets, total credits and receivables and shares in the total deposits) have increased in due course of time. To cite an example, the share of 10 PD banks in the total deposit base climbed to $7.2 \%$ in 2011 , from a figure of $5.7 \%$ registered in 2003 , while the portion of 11 PD banks increased to $92 \%$, from $88 \%$ during the same corresponding years. The other defined shares followed more or less similar trends. At this juncture, it is worthwhile to point to two disadvantageous and undesirable situations considered as important for the discriminant analyses. First and foremost is the fact that the correlation coefficients among the 21 financial ratios handled in the analyses display multicollinearity and the second item involves the fact that the sector shares are too high for the PD banks. In the preliminary examination conducted on the simple correlation coefficients matrix, the highest correlation coefficients were observed only in the Liquidity (L1, L2 and L3) and Profitability (PRO1 and PRO2) definitions, while the simple correlation coefficients among the remaining ratios were found to range at very low levels. In the discriminant solutions, solely the L3 defined liquidity ratio passed the test among the other variables effectuating the differentiation of the groups and none of the profitability ratios has passed the test. The second impediment appears more of a serious character and significant in nature. This imbalance is bound 
naturally to cause an effect in the differentiation of the PD banks bearing a sector share of above $80 \%$ and the group of NPD banks that possess a share of 7\%. For the solution of this problem, the data relating to the sector shares are excluded from the scope of the type model.

The discriminant analysis was made also a subject matter of detailed and profound multi-group analyses by furthering the differentiation of the two general groups as PDs and NPD banks one more step ahead to embody yardsticks such as bank scale (large-small) and capital ownership (local-private, non-resident and public). In this manner, endeavors were exerted to solicit answers to hypotheses concerning whether primary dealer small (large) banks and non-primary dealer banks of small (large) scale are differentiated. Moreover, the scope of tests also encompassed efforts to discover whether the PD banks are different from the NPD banks in regard to capital ownership. In the continuum of the analysis, focal point of research involved to find out whether the PD banks are differentiated among themselves in terms of size and capital ownership.

\subsection{Findings and Discussions}

Findings are classified in the following order and discussed accordingly: a) differentiation of the PD banks and NPD banks, b) differentiation of the small and large PD and NPD banks, c) differentiation of the PD banks and NPD banks in regard to capital ownership, and d) differentiation of solely the PD banks in terms of scale and capital ownership.

\subsubsection{Differentiation of the PD Banks and NPD Banks}

Subject to the delineations described in the data section, the first discriminant solutions were instrumental in verifying how the PD banks and NPD banks differed by taking into account their 18 key financial ratios, as the study attempts to explore and identify the set of variables and their extent in prompting this differentiation, if existent. The standard discriminant coefficients considered as meaningful and effective in the segregation of the PD banks and the NPD banks are provided here-below. The SPSS program calculated the following coefficients which are most influential in the differentiation of the PD and the NPD groups in a manner that would enable the standard distance between the two groups to reach the maximum reading. The ratios regarded as wielding effect in the differentiation of the groups are determined on the basis of their absolute values regardless of their signs. The signs, meanwhile, accentuate the direction of the effect (i.e. negative, positive). According to this outcome, the ratios that are instrumental in differentiating the PD banks and NPD banks from each other in the most effective way are lined up in the order of importance and significance as asset quality with two different definitions, an operational ratio with single definition, two different definitions of capital adequacy ratios, a single-definition liquidity ratio and two-definition operating ratios. As may be deduced from the table, the discriminant values that underscore the differentiation are positive for four ratios, and in the direction of negative for the other three ratios (OR, CA3 and OR2).

Table 2. Standard Discriminant Coefficients and Test Statistics

\begin{tabular}{ll}
\hline Ratios & Coefficients \\
\hline AQ3 Total Credits and Receivables/Total Assets & 1,170 \\
AK2 Financial Assets (Net) / Total Assets & 0,956 \\
OR1 Personnel Expenditures + Severance Payments / Total Assets & $-0,860$ \\
CA3 (Equity Resources-Fixed Assets) / Total Assets & $-0,664$ \\
CA2 Equity Resources / Total Assets & 0,653 \\
L3 FC Liquid Assets / FC Liabilities & 0,460 \\
FR2 (Personnel Expenditures + Severance Payment) / Personnel Number & $-0,264$ \\
Wilks' $\Lambda$ & $0,571^{* *}$ \\
\hline
\end{tabular}

The Wilk's lambda statistics depict that the linear discriminant correlation below:

$$
Z=1.170 A K 3+0.956 A K 2-0.860 F R 1-0.664 S Y 3+0.653 S Y 2+0.460 \text { L3 -0.264 FR2 }
$$

It implies that vectors yielding the variables of the two groups differ meaningfully from a statistical angle. The above correlation is capable of singularly explaining $80 \%$ of the total variance.

As a histogram, the Figure 1 illustrates the frequency breakdown of the discriminant values (again in a standardized format) of the two bank groups comprising the PD and NPD banks, calculated by means of discriminant standard coefficients. The first prominently eye-catching finding in the figure is the perception that the PD and NPD banks are differentiated and disengaged from each other, albeit just a bit. In this way, the linear correlation above faultlessly classifies $82 \%$ of the PD banks as PD and $71 \%$ of the NPD banks as NPD banks. 


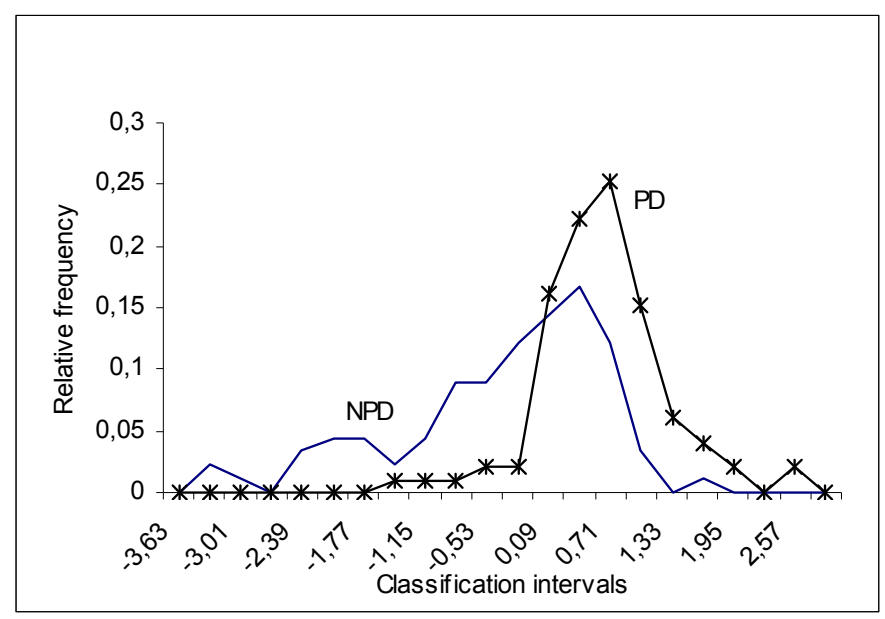

Figure 1. Discriminant Value Breakdown of PD Banks and NPD Banks, 2003-2011

The second finding in Figure 1 that attracts immediate attention is that the average discriminant values of the PD banks are higher by 12 percentage points in comparison with the figure of the NPD banks (93 and 81) and, conversely, the standard deviation of the PD banks is approximately half of the number attained for the NPD group $(7,6$ and 12,5). All of these results point out that the PD banks are further ahead of the NPD banks in ratios that are deemed as meaningful, and that they are in much closer proximity and are converged in a rather consolidated configuration and status. This phenomenon could be construed also as an evidence that the PD banks behave in a disciplined manner, to a great extent, in the underlined ratios. At any rate, it would be feasible to ponder that there exist trivial details underlying this general assessment (such as bank size and the capital ownership). For example, it is worthwhile to contemplate on the nature of developments and transformation that have taken place in the key ratios of the PD banks and NPD banks.

\subsubsection{Differentiation of Small and Large PD Banks and NPD Banks}

There is an abundant source of reference that would substantiate and justify the proposition that the sizes of the banks play an active role in the banks' performances (Note 16). The below section contains summarized findings and key points on how the sub-groups of the small-PD banks and small NPD banks as well as the sub-groups composed of large PD banks and large NPD banks differ from each other. For the stated purposes, and depending on their active shares in the PD and NPD groups, the associated group definitions were offered in regard to below-median (small) and above median (large) classifications and the analyses were furthered again on the basis of the crucial 18 ratios.

The histograms appearing in Figure 2a and Figure $2 b$ clearly signify the size effect in the differentiation of the PD banks and NPD banks. From a reading of the figures, it is possible to deduce the conclusion that the bank size is effective, to the highest degree, in the differentiation of the PD banks and the NPD banks. In Figure 2a, it is noticeable that the small PD banks are tilted rather towards left, in contrast to the consensus anticipations. In plain words, they harbor comparatively lower discriminant values in respect of the small NPD banks. Nonetheless, the fact that its standard deviation is lower denotes that they display a more similar behavior and pattern in the ratios that underscore the differentiation in regard to the NPDs.

Regarding Figure $2 b$, however, it is evident that the large-scale PD banks are inclined towards right with a significant curve, in comparison with the NPD banks.

The diversity in the breakdowns is traceable to the fact that the ratios that account for the differentiation are of extremely versatile content (see below table). For example, in the category of the small banks, while the Revenues-Expenditures ratios have assumed significance among the ratios that differentiate the PD banks and the NPD banks, such ratios were not considered as meaningful in the cases of the large-scale banks. On the other hand, in the large-scale banks grouping, the profitability (PRO1) and liquidity (L3) ratios were added to the ratios that accentuate the distinction between the PD and NPD banks. 


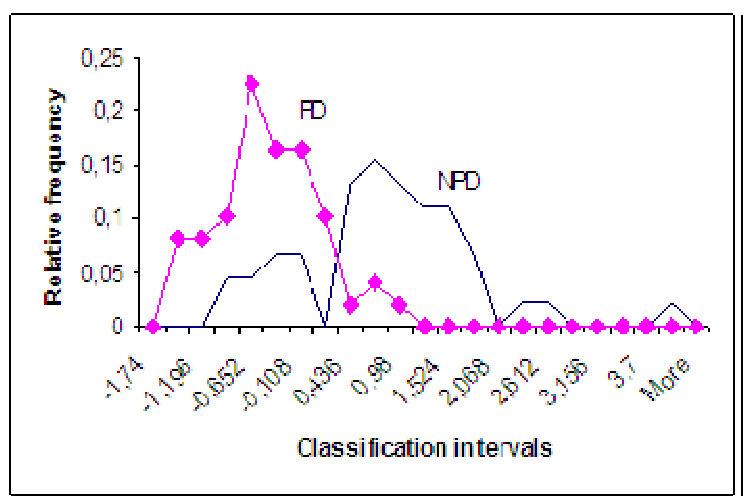

Figure 2a. Discriminant Value Breakdown of Small PD Banks and NPD Banks

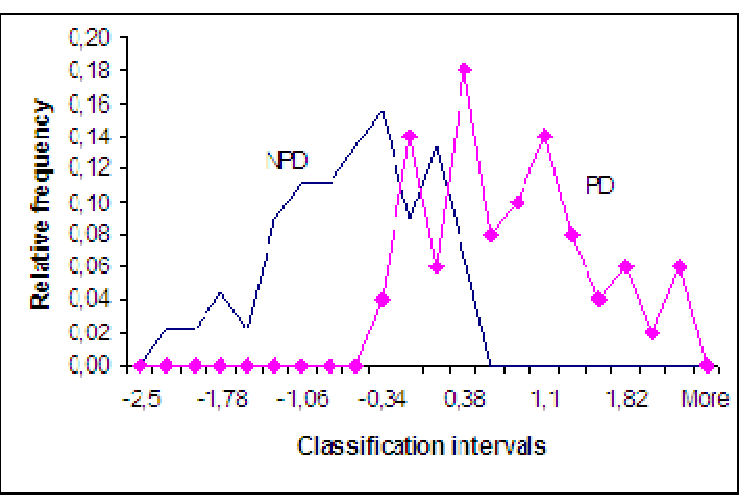

Figure 2b. Discriminant Value Breakdown of Large PD Banks and NPD Banks

Table 3. Ratios Accentuating Differentiation

\begin{tabular}{llll}
\hline $\begin{array}{l}\text { Small Banks } \\
\text { (PD and NPD) }\end{array}$ & & \multicolumn{2}{l}{$\begin{array}{l}\text { Large Banks } \\
\text { (PD and NPD) }\end{array}$} \\
\cline { 1 - 2 } Ratio & Coefficient & Ratio & Coefficient \\
\hline CA1 & 0,775 & CA2 & 1,245 \\
RE2 & $-0,720$ & OR1 & $-1,049$ \\
OR2 & 0,549 & CA3 & $-0,985$ \\
CA3 & 0,465 & AQ2 & 0,814 \\
AQ2 & $-0,449$ & OR2 & 0,680 \\
RE3 & $-0,377$ & PRO1 & 0,465 \\
& & L3 & 0,266 \\
Wilks' $\Lambda$ & $0,478^{* *}$ & & $0,181^{* *}$ \\
\hline
\end{tabular}

The discriminant correlations provided above proved successful at the proportion of $86 \%$ in classifying the small banks as PDs and NPDs, as this achievement in the case of large banks has reached 98\%.

\subsubsection{Differentiation of the PD and NPD Banks in Terms of Capital Ownership}

The question whether the capital ownership induces a differentiation in the ratios of the PD banks and NPD banks may offer some clues to the official regulatory and supervisory institutions in charge of the banking community. For this purpose, discriminant analyses were used to determine to what extent and which of the 18 financial ratios were functional in differentiating the PD-private, PD-non-resident and NPD-private and NPD-non-resident banking groups during the 2003-2011 period under scrutiny. Since the NPD banks featured no state-owned or public banks, the state and public banks were naturally left out of the scope of the analysis at this stage. The Figure 3 displays the separate breakdown of the discriminant values of the four sub-groups.

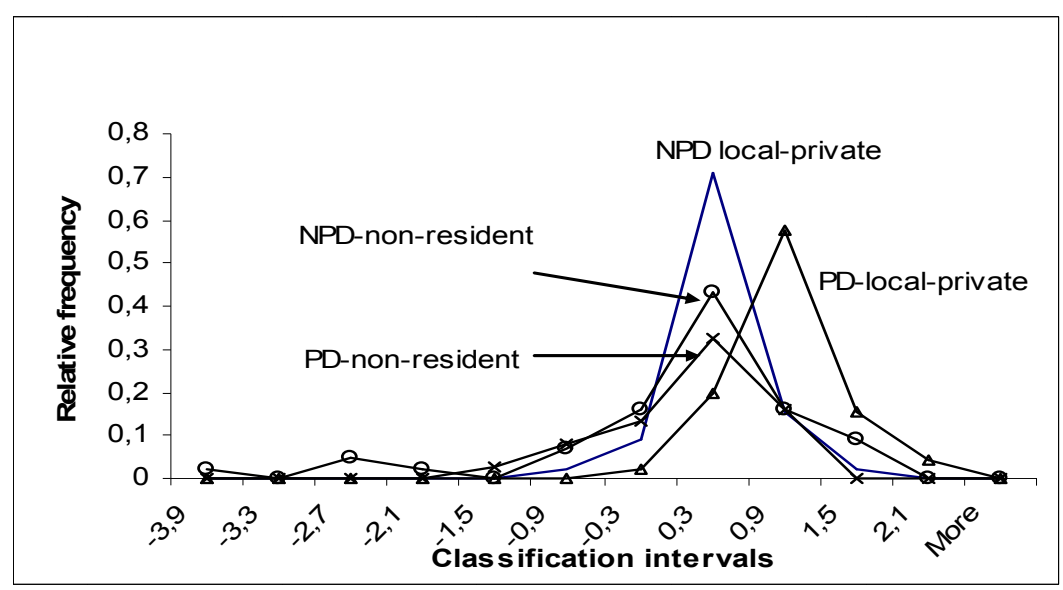

Figure 3. Breakdown of the Discriminant Values of PD and NPD Local-Private and Non-resident Banks 
The first of the three linear discriminant correlations that secure this differentiation was used for the frequency spread as shown in the above Figure. This correlation represents singularly $60 \%$ of the total variance. Although the contributions of the second and third correlations are $40 \%$, the breakdowns failed to signify any noteworthy changes when taken into consideration.

The foremost strong ratios that differentiate the banks' four sub-groups can be identified as: Operational ratio-OR1, Capital adequacies-CA3-CA2, Asset qualities-AQ2-AQ3-, Liquidity-L2 and Revenues-Expenditures-RE1 ratios. However, as it may be observed from the contents of the Figure, the differentiation among the groups does not portray a noteworthy appearance. The most concrete differentiation took place in the PD-local-private banks and NPD-local-private banking groups. This differentiation could be best explained in the following manner: when local-private banks become eligible to operate as PD, it was found that they have exhibited a more favorable performance for the ratios that were taken into consideration for the NPD local-private banks. Another point that attracts attention as inferred from the figure is that there was virtually no differentiation among the foreign banks' PD and NPD sub-groups. This implies that the PD non-resident banks and the NPD non-resident banks have attained similar performances in the primary financial ratios under focus, demonstrating that the end-results in these ratios were not different or divergent.

\subsubsection{Differentiation of Banks in Terms of Capital Ownership}

Finally, this section also deals with the question of how solely the PD banks are differentiated among themselves in respect of capital ownership and, if valid, what are the more significant ratios that instigate such a divergence.

The Figure 4 exhibits how the PD banks are differentiated in regard to their capital ownership during the period that encompasses the years 2003 through 2011, based on meaningful ratios. The discriminant coefficients that enabled the emergence of this differentiation can be identified as: Asset quality-AQ3, Operational ratios-OR3-OR1-OR2 and Revenues-Expenditures ratios-RE1-RE3. What deserves attention at this point is the finding that three of the Operational ratios and two of the Revenues-Expenditures ratios were effective in this differentiation.

Although the coefficients of the discriminant correlations are not supplied, the capability of the mentioned correlation to forecast the groups is $86 \%$. In other words, there appears a $14 \%$ uncharted and unknown space, in general terms, when undertaking a grouping of the banks.

One of the most significant findings that crop up from the contents of the Figure 4 is that there are notable differentiations in the breakdown of the PD banks in respect of capital ownership. The local-private bank group that is placed at the mid section of Figure 4 displays rather a more concentrated (having a smaller standard deviation) character, in comparison with the other banks. In other words, the local-private banks classified in the PD group have furnished similar, look-alike performances insofar as the leading ratios are concerned. Although the frequency breakdown of the foreign banks is placed at the extreme right section, their disbursement (implying the heterogeneous structure in their ratios) is most visible at first sight. The state-owned and public banks also attract attention as they appear tagged with comparatively higher standard deviation vis-à-vis the local-private banks, placing them at the extreme left section.

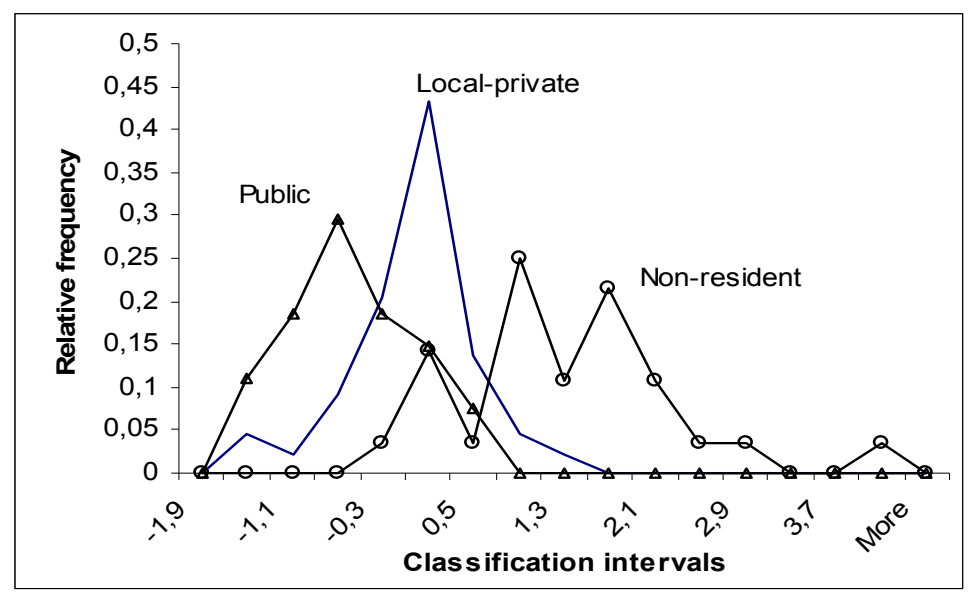

Figure 4. Discriminant Value Breakdown of PD Banks in Terms of Capital Ownership 


\section{Conclusions}

Undergoing through significant transformation as a consequence of the successive November 2000 and February 2001 crises, the Turkish economy was confronted with a number of innovative implementations in several fields. Designed and conceived with the ultimate purpose of contributing to and sophisticating particularly the domestic borrowing functions, accomplishing the most favorable cost via most plausible risk premium and also providing transparency to the market operations, the primary dealership system was put into practice, in the real sense of the concept, effective from the year 2003. This study, initiated originally to determine whether operating as a primary dealer, from the perspective of the banks, would be reflected on their financial structures, has yielded various findings, in a statistical context.

In the analysis, conducted on the basis of the financial data pertaining to the period of 2003 through 2011, two banking groups (the PD and NPD) were subjected to a profound comparison on a set of aspects.

The findings obtained at the end of the analyses carried out are:

The most basic indicators that manifested the differentiation of the PD banks from the NPD banks, from the vantage point of the PD banks, were elevated profitability, heightened market shares and lower operating ratios. During the period under examination, the PD banks persisted in fostering their market shares, but there was also a discernible upswing in the market shares of the NPD banks. At any rate, since there was a considerable gap between the market shares of the PD banks and the NPD banks, the data related to the sector shares were excluded from the scope of the present study, specifically in the ensuing phase of the analysis.

At the end of the discriminant analysis, the following observations were derived from the ratios, perceived as contributing materially to the differentiating the PD banks and the NPD banks:

- There were more loans in the total assets of the PD banks;

- They retained a higher ratio of financial assets in their balance sheets (this could be assessed as a re-confirmation of the anticipated natural and corollary result);

- The shares of the equity resources in their balance sheets were higher;

- Liquidity was at a higher level, but, on the contrary, it was observed that;

- The expenditures related to their employees were at a higher ratio;

- They were at a lower level in regard to free capital;

- The averages of the data pertaining to the PD banks were in close proximity in comparison with the NPDs, implying that they had an evident convergence from the financial perspective and that they acted in a more disciplined manner at the same time.

In the comparison study performed on the scales and sizes of the PD banks and NPD banks, the ratios relating to the revenues-expenditures group were most conspicuous among the ratios that possessed negative-effect and bearing a differentiating aspect for the small-scale category, while it was noted that this ratio group played virtually no role in the differentiation of the large-scale PD banks and NPD banks, and that more and more profitability, as well as liquidity ratios assumed prominence, thereby imparting a positive impact, and cultivating the emergence of the following findings:

- The discriminant values of the small-scale PD banks ranged at lower levels in regard to the small-scale NPD banks but it was noticed that they acted in a disciplined manner among their group, owing essentially to the fact that their standard deviations were restrained.

- The most important and influential aspects of the differentiation that defined the large-scale PD banks and the small-scale NPD banks appeared as the capital adequacy, asset quality and operational ratios.

In the analysis conducted in terms of capital ownership, efforts were made to detect the most important differentiation element between the privately-owned local PD banks and the privately-owned NPD banks as well as the non-resident PD banks and the non-resident NPD banks, generating the following results:

- The differentiation among the non-resident PD banks and the non-resident NPD banks was not too discernible, and utilizing this point as a springboard, it could be confidently asserted that functioning as a primary dealer would cause no significant alteration in the status of the non-resident banks, from a financial point of view.

- The differentiation was most manifest between the privately-owned PD banks and the privately-owned NPD banks, prompting assumptions that functioning as a primary dealer would cause a tangible modification and rectification in the status of the local privately-owned banks, again from a financial point of view. 
As a final remark, the noteworthy points that surface when a study is performed among the PD banks on specific areas where they are differentiated in their own group in terms of financial behavior could be summarized as:

- Among the PD banks, the frequencies of the state and public banks are higher in comparison to the values produced by the other PD bank groups.

- The discriminant values of the local-capital PD banks appear at the middle among the three groups, and it was observed that they constitute the group with the lowest standard deviation. In plain terms, this banking group displays more inter-group resemblance, construed from a financial viewpoint.

- As for the non-resident PD banks, it was witnessed that they harbored the highest discriminant values but the fact that the standard deviation among themselves are higher underlines the outcome that they exhibit dissimilarity from a financial movement point of view.

Conclusively, it was observed that functioning as primary dealer imparted a direction on the banks' financial movements; that this status was a primary factor in their differentiation from the non-primary dealer banks and that the effects of this differentiation were more evident among the local-capital banks in regard to the non-resident banks. At the same time, among the PD banks, it was concluded through the analytical evidence that the state-owned and public PD banks possessed lower average values in comparison with the values belonging to the privately-owned local and non-resident banks.

\section{References}

Arnone, M., \& Ugolini, P. (2005). Primary Dealers in Government Securities. International Monetary Fund.

Atasoy, H. (2007). Revenues-Expenditures Analysis and Determinants of Profitability Performance in the Turkish Banking Sector. Dissertation for Professional Proficiency at the RT Central Bank, Banking and Financial Institutions Directorate General, Ankara.

Aydın, A. B. (2005). Primary Dealership System, Selected Country Cases and Implementation in Turkey. Dissertation for Professional Proficiency, RT Central Bank, Markets Directorate General, Ankara.

Bankalarımız. (2011). Our Banks. TBB, www.tbb.org.tr.

Breuer, W. (1999). The Relevance of Primary Dealers for Public Bond Issues. CFS Working Paper, No. 1999/11.

Demir, M. V. (2004). Public Budget Specialization Research Report, Innovations Introduced by Law No. 4749 on Regulations Concerning Public Financing and Debt Management, and Comparison with the Preceding Regulations. www.bumko.gov.tr.

Flury, B., \& Riedwyl, H. (1990). Multivariate Statistics-A Practical Approach. Chapman and Hall.

Kayal, M. M., \& Ünal, S. (2005). Market Microstructure, Liquidity of Financial Assets and Price Formation. Dumlupinar University Social Sciences Journal, (12), 1-14.

Koçyiğit, D. (2009). Monetary Policy Instruments Employed During Ordinary and Extraordinary Situations and Liquidity Management Strategies. Dissertation for Professional Proficiency, RT Central Bank, Money Markets Directorate General, Ankara.

Krzanowski, W. J. (1988). Principles of Multivariate Analysis-A User's Perspective. Clarendon Press-Oxford.

Rencher, A. C. (1995). Methods of Multivariate Analysis. John Wiley and Sons, Inc.

RT Central Bank. (2002, September 3). Press Release, numbered 2002-73. www.tcmb.gov.tr.

Sareen, S. (2011). Commodity Bundling in Government Securities Auctions: An Analysis of the Primary Dealer Model in Canada. Berkeley Research Group, New York.

Sokolov, V. (2011, March). The Impact of Primary Bond Dealers. Maturity Choice on Repo Market Interest Rates. Social Science Research Network.

Srivastava, M. S., \& Carter, M. E. (1983). An Introduction to Applied Multivariate Statistics. North-Holland.

Taşkın, F. D. (2011). Factors Influencing Performances of Commercial Banks in Turkey. Ege Akademik Bakış, 11(2), 289-298.

TBB. (2012, March). Turkish Banks Association. Statistical Data. Quarterly Bank Data, all periods, www.tbb.org.tr.

Treasury Undersecretariat. ( 2003-2004). Primary Dealership Contract, www.hazine.gov.tr.

Treasury Undersecretariat. ( 2008-2009). Primary Dealership Contract, www.hazine.gov.tr. 
Treasury Undersecretariat. (2004-2005). Primary Dealership Contract, www.hazine.gov.tr.

Treasury Undersecretariat. (2005-2006). Primary Dealership Contract, www.hazine.gov.tr.

Treasury Undersecretariat. (2006-2007). Primary Dealership Contract, www.hazine.gov.tr.

Treasury Undersecretariat. (2007-2008). Primary Dealership Contract, www.hazine.gov.tr.

Treasury Undersecretariat. (2009-2010). Primary Dealership Contract, www.hazine.gov.tr.

Treasury Undersecretariat. (2010-2011). Primary Dealership Contract, www.hazine.gov.tr.

Treasury Undersecretariat. (2011, December 16). Press Release, Primary Dealership Eligibility Criteria for 2012. www.hazine.gov.tr.

Yıldız, S. (2011). A Research in the Banking Sector on Measuring Business Administration Management. Erciyes Erciyes University Journal, (36).

Y1lmaz, B. E. (2005). The Primary Dealership System in Public Debt Management. Istanbul University, Faculty of Economics, Finance Department Finance Research Center Conferences, Serial No. 47.

\section{Notes}

Note 1. Under the regulations prevalent during the underlined term, the Capital Adequacy Ratio (CAR) was obtained by dividing the capital base with the total of the risk-weighted assets and non-cash liabilities.

Note 2. "Foreign Currency Net General Position": calculation of the position during the underlined term was conducted on the basis of the differential of the Turkish Lira equivalents accrued between the aggregate of the foreign currency assets and the foreign currency liabilities.

Note 3. Capital Base: the worth of a company obtained by reduction of values from the stockholders' equity plus loans and retained profits.

Note 4. Denotes the outright purchase-and-sale transactions conducted on the Istanbul Stock Exchange's (ISE) Bonds and Bills Market as well as the securities registered in the ISE in compliance with rules and regulations.

Note 5. Determined on the basis of the 1999 values, and subjected to re-valuation during the subsequent periods.

Note 6. Determined on the basis of the 1999 values, and subjected to re-valuation during the subsequent periods.

Note 7. Compiled from the Treasury Undersecretariat's Press Release dated December 16, 2011.

Note 8. Denotes the ratio calculated on the basis of the "Regulation on Measurement and Evaluation of Liquidity Adequacy of Banks," issued and promulgated by the BRSA, and dated October 1, 2006.

Note 9. Denotes the outright purchase-and-sale transactions conducted on the ISE's Bonds and Bills Market as well as the transactions submitted to the ISE solely for registration purposes.

Note 10. Rights, privileges and liabilities of the primary dealers are excerpted from the headings contained in the "Primary Dealer Contract" specimen text, prepared by the Treasury Undersecretariat.

Note 11. Non-Competitive Bid: the bid submitted on auction day until 10:30 a.m. to purchase the auctioned security from the average price of the auction or the price determined at the auction.

Note 12. "TAP sales": the Treasury Undersecretariat keeps the Floating Rate Notes, bearing maturities of up to maximum five years, at the Central Bank of Turkey, accessible by investors at their own discretion for purchase. As long as the Notes are not purchased, their ownership belongs to the Treasury. The Central Bank acts as an intermediary in this case." (Demir, 2004)

Note 13. The Undersecretariat organizes meetings at least once in a month with the primary dealers and, depending on the subject matter on agenda for the scheduled sessions and deliberations, may summon representatives from other public and government agencies and institutions. Upon the express demand of the Undersecretariat, the primary dealers may inform the Primary Dealer Consultative Board on matters pertaining to daily economic issues.

Note 14. Except for the start-up year under focus, the number of primary dealer banks operating in the market was uniformly 12 for all other years but, since Deutsche Bank was a single-branch entity and for that particular reason its ratios would portray a starkly different outlook in comparison with the other banks, it was left out of the scope of the foregoing analysis, leaving 11 banks behind as primary dealers for due review.

Note 15. Priorities were determined by us on the basis of consultations conducted with reference persons reputed for their specialization and expertise in the field of banking. 
Note 16. Taşkın. 2011, Atasoy.2007, Yıldız. 2011.

\section{Appendixes}

Appendix 1a. Banks Selected Initially as Primary Dealers (2000)

1. ABN-AMBRO Bank,

2. Akbank,

3. Alternatifbank,

4. Chase Manhattan,

5. Citibank,

6. Demirbank,

7. Dişbank,

8. Finansbank,

9. Garanti Bankası,

10. İktisat Bankası,

11. Kentbank,

12. Koçbank,

13. Körfezbank,

14. Osmanlı Bankası,

15. Türk Ekonomi Bankası,

16. İş Bankası,

17. Ulusalbank,

18. Vakıfbank and

19. Yapı Kredi Bankası.

Appendix 1b. Primary Dealer (PD) Banks 2003-2011*

\begin{tabular}{|c|c|c|c|c|c|c|c|}
\hline 2003-2004 & 2004-2005 & 2005-2006 & 2006-2007 & 2007-2008 & 2008-2009 & 2009-2010 & 2010-2011 \\
\hline \multirow[t]{2}{*}{ Akbank } & Akbank & Akbank & Akbank & Akbank & Akbank & Akbank & Akbank \\
\hline & Deutsche Bank & Deutsche Bank & Deutsche Bank & Deutsche Bank & Deutsche Bank & Deutsche Bank & Deutsche Bank \\
\hline Finansbank & Finansbank & Finansbank & Finansbank & Finansbank & Finansbank & Finansbank & Finansbank \\
\hline HSBC & HSBC & HSBC & HSBC & HSBC & HSBC & HSBC & HSBC \\
\hline Oyakbank** & Oyakbank & Oyakbank & Oyakbank & Oyakbank & ING Bank & ING Bank & ING Bank \\
\hline Ziraat & Ziraat & Ziraat & Ziraat & Ziraat & Ziraat & Ziraat & Ziraat \\
\hline D1şbank $* * *$ & Dişbank & Dişbank & Fortis & Fortis & Fortis & Fortis & TEB \\
\hline Garanti & Garanti & Garanti & Garanti & Garanti & Garanti & Garanti & Garanti \\
\hline Halk & Halk & Halk & Halk & Halk & Halk & Halk & Halk \\
\hline İş & İş & İş & İş & İş & İş & İş & İş \\
\hline Vakıflar & Vakıflar & Vakıflar & Vakıflar & Vakıflar & Vakıflar & Vakıflar & Vakıflar \\
\hline Yap1 ve Kredi & Yap1 ve Kredi & Yap1 ve Kredi & Yap1 ve Kredi & Yapı ve Kredi & Yap1 ve Kredi & Yap1 ve Kredi & Yap1 ve Kredi \\
\hline
\end{tabular}

Source: Treasury Undersecretariat.

Note: * From the date of commencement of the system's implementation, 11 banks were qualified to act as primary dealers in the first year, followed by 12 banks operating as primary dealers in the subsequent years. However, effective from 2004, Deutsche Bank, as a primary dealer, was a single-branch entity and, for that particular reason, its ratios would portray a starkly different outlook in comparison with the other banks, as it was left out of the scope of the analysis, leaving 11 banks behind as primary dealers for due review. ** Oyakbank began to use the title of ING Bank effective from 2008. *** In the initial years, Dışbank took place in the system but its name was subsequently changed to Fortis, enabling the same bank to operate under a different title and its corporate entity was dissolved as a consequence of its merger with T. Ekonomi Bankası, and prevailed in the system as T. Ekonomi Bankası effective from that date onwards. 
Appendix 1c. Non-Primary Dealer (NPD) Deposit-Taking Banks 2003-2011

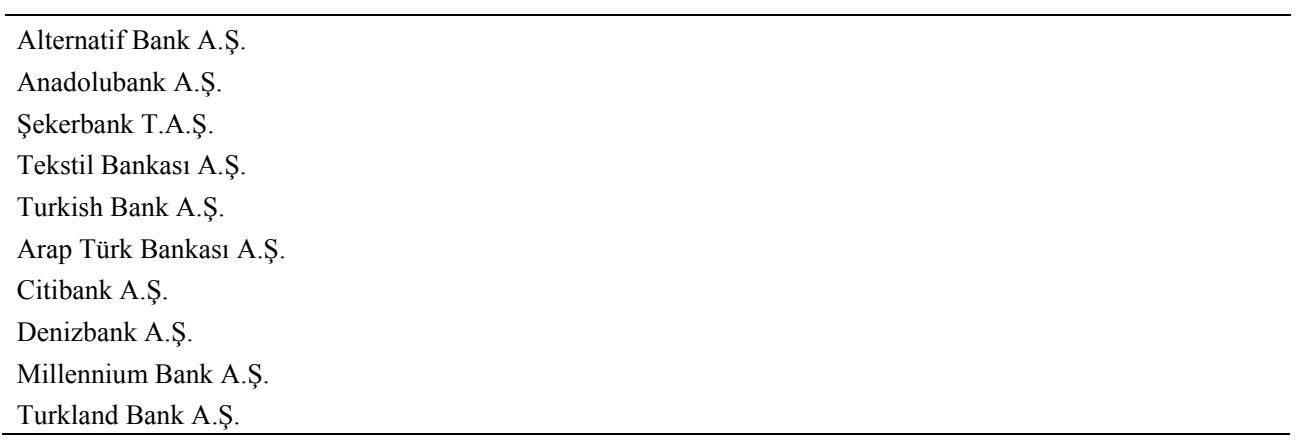

Appendix 2. Ratios Used in the Analysis

\begin{tabular}{ll}
\hline CA & CA1-Equity Resources / (Credits + Market + Amount Exposed to Operational Risk) \\
& CA2- Equity Resources / Total Assets \\
& C3- (Equity Resources-Fixed Assets) / Total Assets \\
\hline AQ & AQ1- Non-Performing Loans (gross) / Total Loans and Receivables \\
& AQ2- Financial Assets (Net) / Total Assets \\
& AQ3- Total Loans and Receivables / Total Assets \\
\hline L & L1- Liquid Assets / Total Assets \\
& L2- Liquid Assets / (Deposits + Non-Deposit Resources) \\
& L3- FC Liquid Assets / FC Liabilities \\
\hline PRO & PRO1- Net Period Profit (Loss) / Equity Resources \\
& PRO2- Net Period Profit (Loss) / Total Assets \\
& PRO3- Net Period Profit (Loss) / aid-in Capital \\
\hline RE & RE1- Interest Income / Interest Expenditures \\
& RE2- Total Revenues / Total Expenditures \\
& RE3- Interest Income / Total Revenues \\
\hline OR & OR1- (Personnel Expenditures + Severance Payments) / Total Assets \\
& OR2- (Personnel Expenditures + Severance Payments) / Personnel Number (thousand TL) \\
& OR3- Severance Payments / Personnel Number (thousand TL) \\
\hline SS & SS1- Total Assets \\
& SS2- Total Loans and Receivables \\
& SS3- Total Deposit Base
\end{tabular}

Source: Ratios excerpted from the "Our Banks" periodical published by the TBA. 